\title{
Adriaan Reland (1676-1718): Early Modern Humanist, Philologist and Scholar of Comparative Religion
}

\author{
Bart Jaski, Christian Lange, Anna Pytlowany, and HenkJ. van Rinsum
}

\begin{abstract}
Grelot's journey to Constantinople [is] certainly a book worth reading and often aroused a great desire in me to go and see Constantinople myself, a desire that I would certainly have fulfilled if fate had allowed me to live as I wished. ${ }^{1}$
\end{abstract}

Reland, a judicious student, had travelled over the east in his closet in Utrecht. ${ }^{2}$

This book covers the intellectual achievements of a remarkable man: Adriaan Reland, professor of Oriental languages at the University of Utrecht from 1701 to 1718 . Born in a village in North Holland, Reland never travelled beyond the borders of his home country. However, he had an astonishingly broad worldview. He spent much of his working life in his study, where he read about the world of the Orient, fashioning himself into a central figure and a point of exchange between scholars, publishers, antiquarians and collectors, as well as Dutch East India Company officials, travellers, and Calvinist missionaries overseas. This book illustrates Reland's many accomplishments. It follows his

1 'Ita \& Grelotus in itinerario Constantinopolitano (libro sane lectu dignissimo, \& qui vehemens saepe in me desiderium excitavit ipsam Constantinopolin adeundi, cui profecto satis facerem, Me si fata meis paterentur vivere vitam Auspiciis)'. See Reland, De religione Mohammedica (1705), p. 151. Guillaume-Joseph Grelot (1630-1680) published his Relation nouvelle d'un voyage de Constantinople in 1680.

2 Gibbon, Decline and Fall of the Roman Empire, vol. 5, p. 114 n. 101. 
scholarly trajectory as an Orientalist, a linguist, a cartographer, a poet, and a historian of comparative religion.

\section{$1 \quad$ Reland's Life}

The chapters of this book illuminate specific aspects of Reland's biography. Here, we offer only a brief sketch. ${ }^{3}$ Reland was born in De Rijp, a small village between Alkmaar and Purmerend, on 17 July 1676 . His father Johannes had just accepted a position as a Dutch Reformed Church minister in Alkmaar, and soon afterwards moved to Amsterdam. Reland therefore also called himself an Amsterdammer, in addition to identifying himself as a Rijpenaar. Reland was the eldest of two sons; his younger brother Peter later worked in the judiciary. His father quickly recognised his elder son's precocious academic talents and in 1687, at the age of eleven, sent him to the Athenaeum Illustre in Amsterdam. ${ }^{4}$ One of Reland's teachers there was Petrus Francius (1645-1704), professor of rhetoric, who introduced him to poetry. Reland became acquainted with the Latin and Greek classics and with the liberal arts. Willem Surenhuizen (c. 1664-1729) and Everard van der Hooght (1642?-1716) taught him Hebrew (and possibly some Arabic).

In 169o, at the age of fourteen, Reland entered the University of Utrecht. In the first four years he read philosophy, then for the next two years he focused on theology. During this time, he lived in the house of Melchior Leydecker (1642-1721), a professor of theology who was also skilled in Oriental languages. The university's Album studiosorum of 1694 mentions the student 'Adrianus Relandus Ripa-Batavus.' In that year, which fell under the rectorate of Johannes Munnicks, about seventy students were registered at the university, one third of whom came from abroad. Around that time, Reland befriended the German student Heinrich Sike (Sikius) (1669-1712), who taught him Arabic. In 1696 we find them in Leiden at the auction of the manuscripts of the deceased professor of mathematics and Arabic, Jacobus Golius (1596-1667). Years later, Utrecht awarded Sike an honorary doctorate, which facilitated Sike's appointment as a professor of Hebrew at Cambridge in 1705 .

3 This is based, for the most part, on a number of short biographies of Reland in Dutch, including Van der Aa, 'Relandus', Van Amersfoort, 'Adrianus Reland', Hoek, '3oo jaar Adriaan Reland', and Van Rinsum, '1705'. In some of the articles of Alastair Hamilton, a prominent scholar on Reland, the reader may find biographical information in English. See also Vrolijk and Van Leeuwen, Arabic Studies in the Netherlands, pp. 65-72.

4 The Atheneum Illustre, a city-sponsored school, provided propaedeutic education for the university.

5 Album studiosorum, p. 92. 
In September 1694 Reland defended his doctoral thesis, a disputatio entitled De libertate philosophandi (About the liberty to philosophize) but he was only given the title of Philos. Doctor et A.L.M (Doctor of Philosophy and Artium Liberalium Magister) on 18 February 1699. Reland continued his education at the University of Leiden, where from 1697 to 1698 he attended lectures by the two theologians, Johannes à Marck (1656-1731) and Friedrich Spanheim (16321701). He also followed the classes of Wolferdius Senguerdius (1646-1724), professor of experimental physics, best known for his air-pump, a device he liked to demonstrate during his lectures. In the meantime, Reland gave private lessons to Henry (1682-1726), the son of Hans Willem Bentinck (1649-1709), Count of Portland, the most important advisor and confidant of Stadholder/ King William III (1650-1702). When he was asked to join the court in England to continue Henry's education, Reland declined, albeit reluctantly, because of his father's ill health. Later he was asked to become a professor at the University of Lingen, an appointment he also declined.

Finally, in 1699, he accepted an offer from the University of Harderwijk to teach experimental physics. His inaugural lecture in 1700 in Harderwijk dealt with the development of the new philosophy of his age (De incremento quod Philosophia coepit hoc seculo). Probably due to his personal connections with the higher political circles, in that same year he got an offer from the authorities of the University of Utrecht to teach Oriental languages, which he accepted, and from 1713 he also taught Biblical Antiquities (antiquitates sacri). He lived and worked in Utrecht from 1701 until his untimely death in 1718. In 1702, in a small church in Doorn, near Utrecht, Reland married the daughter of a former mayor of Zierikzee, Johanna Catharina Teelinck. They lived in the Domsteeg in Utrecht and had two daughters and a son. During his professorship at Utrecht Reland received prestigious offers from the universities of Franeker and Leiden, but on both occasions he decided to stay in Utrecht. In 1708/1709 he served as Rector Magnificus of the university. On February 5, 1718, at the age of 41 , Reland died suddenly from smallpox.

\section{Arabist, Cartographer, Antiquarian and Student of Comparative Religions}

The impact of Reland's most well-known work, the 1705 'manifesto' $\mathrm{On}$ the Mohammedan religion (De religione Mohammedica), can only be called transformative. However, we should beware of reducing Reland to the status of a defender of Islam. Nor should we pigeonhole him as an 'enlightened Christian',

6 Bevilacqua, Republic of Arabic Letters, p. 83. 
or a 'Cartesian', or a 'radical philosopher'. Instead, as Henk J. van Rinsum argues in the opening chapter of this book, Reland's personality and intellectual life was much more complex: he was, amongst other things, an 'apologetic, reformed theologian' as well as 'an early Enlightenment Cartesian thinker'. He was a new type of scholar: an Early Modern humanist. Guy Stroumsa has suggested that the modern study of religion did not start in the second half of the nineteenth century, but around the turn of the seventeenth century, with critical philology and methodological skepticism at its core, and with Reland as one of its main protagonists. ${ }^{7}$ Reland thus emerges as an early harbinger of modern Religionswissenschaft, the study of religion that is no longer subservient to Christian missiology. His work owes as much to the rationalism and methodological rigour of Robert Boyle (1627-1691), Francis Bacon (1561-1626) and René Descartes (1596-1650) as it does to critical ad fontes philology and to the humanism of the likes of Montaigne (1533-1592) and Erasmus (1466-1536).

Reland's primary interest, it should be noted, was in languages and textual traditions. His excellent classical education is most clearly visible in his devotion to the Latin Muse. Dirk Sacré's chapter in this volume introduces Reland's Neo-Latin love elegy Galatea, a poem that Reland worked on until the end of his life, resulting in about 70 variant readings. Galatea was an international bestseller; it was published, republished and translated in booklet form well into the late nineteenth century. ${ }^{8}$ Reland is especially remembered, however, for his contributions to the study of the three Abrahamic religions, including both their textual and material traditions. His interest in studying religion not from a theological but from a comparative, 'scientific' perspective extended to the geographia sacra, or biblical geography, which led him to produce maps without much reference, let alone deference, to the alleged authority of earlier scholarship. Speaking about the methodology followed in Reland's seminal work Palestina illustrata, Zur Shalev observes that

Reland explains that his main task is one of cleansing - removal of the heaps of assumptions and uncorroborated traditions regarding the geography of the Holy Land. He does not bother to enter into arguments with the fellow researchers, and prefers to construct the map of the land himself, on the basis of compilation and comparison of ancient sources. The maps included by Reland in the book (11 in all), are indeed clean and empty looking, and the reason for this, he explains, is because he refrains

7 Stroumsa, A New Science.

8 In Appendix 4, the reader is offered a taste of Galatea by the fragment Elegies for Galatea, no. 2, in the translation of Jason Harris. 
from mentioning villages and cities whose location is not certain. Reland even censures his predecessors for randomly scattering mountains and rivers on the map. [...] This process of cleansing not only fits in with the ideas of the early Enlightenment, but also with Reland's Protestant beliefs, according to which the Catholic tradition corrupted a purer ancient reality. ${ }^{9}$

Reland's academic career was relatively short, but he was a prolific writer.10 The importance of De religione Mohammedica for the European view of Islam is immense, as several chapters in this book demonstrate. Lot Brouwer notes in her contribution that De religione Mohammedica is a pioneering work, based on a careful selection of primary sources and on rigorous philological analysis. Reland offers a well-considered view of the Islamic religion and refutes many long-lasting misconceptions that had their origins in Christian apologetics and in previous mistranslations of Arabic sources, thus giving an important impulse to the emancipation of the study of Islam as an autonomous discipline. Outside academia, where the work was translated into various vernacular languages, De religione Mohammedica was mainly presented as a source of information about Islam, useful in the fight against its adherents. Nevertheless, it is safe to state that Reland's refutation of traditional misconceptions contributed to the spread of a more balanced view of Islam amongst scholars and the general public alike. In this respect it is quite telling that Reland dedicated De religione Mohammedica to his brother Peter, and that he drew a parallel with his brother's work in the judiciary ('qui \& colis Justitiam', i.e. 'who also fosters Justice'). ${ }^{11}$

Reland's work on Islam had a modest but interesting prelude. As Remke Kruk and Arnoud Vrolijk discuss in their chapter in this volume, Reland was involved in the second edition (1701) of the Dutch translation of the Arabic philosophical allegory, Hayy ibn Yaqzān, by the Andalusian Muslim philosopher Ibn Ṭufayl (d. 1185). The story of Hayy b. Yaqzān ('Living, son of Wakening'), a man growing up on a desert island and reaching the highest levels of practical and theoretical knowledge, including the knowledge of God, has been a source of enduring fascination for European thinkers, and for the advocates of natural theology in particular. Reland was not a follower of natural theology, but his 'global curiosity' drew him to the topic. His annotations to the Dutch Hayy ibn Yaqzān of 1701 give an impression of his broad familiarity with Islamic

9 Shalev, Hadriani Relandi Palaestina, p. 2.

10 Appendix 1 provides an overview of his writings.

11 Reland, De religione Mohammedica (1705), fol. *3r. 
philosophy and theology. Also, we may legitimately assume that Reland was in touch with the mysterious 'S.D.B.', the person responsible for revising the original 1672 Dutch translation. (The identity of 'S.D.B.' is revealed in Vrolijk's chapter.) This circumstance casts an interesting light on the network of translators, booksellers and publishers in the days of our Utrecht professor, as well as on books that were controversial or even forbidden, such as the writings of Spinoza or indeed, later, of Reland himself.

Let us reiterate that Reland was a man of many interests. He was not only interested in Islam, its languages and cultures, but, besides his classical and cartographic studies, he also devoted himself to the study of Hebrew philology, biblical archeology, and numismatics. Reland's significance for the study of Hebrew in particular is hard to overestimate. Reland's works on Jewish antiquities were arguably as significant and influential as his Islamic studies, as Ulrich Groetsch suggests in his contribution. For Reland, Jewish antiquities were more than just texts. To quote Zur Shalev once again, even though 'the era of empirical-scientific biblical archeology had not yet begun' in the time of Reland, he was nonetheless driven by a keen interest in the 'material culture of the Jewish nation', carrying out 'studies of Hebrew and Samaritan coins, Temple rituals and the liturgical vessels from the Temple that Titus took to Rome.12 As for numismatics, Reland assembled his own coin collection and also wrote on the subject. Over the years he gradually moved beyond a concern with Samaritan, Hebrew and Roman coins, and made forays into Middle Eastern and Far Eastern numismatics. In his contribution to this volume, Jan Just Witkam presents an introduction and annotated translation of Reland's 1708 treatise on Islamic gems and seals. The handful of objects discussed by Reland was held largely in the private collections of wealthy members of the Amsterdam bourgeoisie, with whom he maintained friendly connections. Several of the seals are inscribed with short credal statements, including one that bears the entire 112th chapter of the Qur'ann. The treatise also includes copper engravings of the seals, based on what seem to be original drawings by Reland. In his explanatory notes Reland repeatedly cites from letters he wrote to their owners. He expresses admiration for the beauty of the seals' calligraphy and impresses upon his upper-class friends the message he had already announced in De religione Mohammedica a couple of years earlier, namely that Muslim culture has much to recommend itself and should not be dismissed out of hand. 
There is no better way to appreciate the scope of Reland's scholarship than to browse through the 1718 sales catalogue of his Nachlass, as well as the catalogue of his manuscripts, auctioned off in 1761. In his chapter on 'The manuscript collection of Adriaan Reland in the University Library of Utrecht and beyond', Bart Jaski notes a formidable obstacle encountered by Reland upon his appointment to the Utrecht chair: he found the university library illstocked with Oriental manuscripts. There were only a few dozen, most of them in Hebrew. As Jaski explains, Reland consequently had to acquire Oriental literature on his own initiative and with his own means. On the whole he either bought manuscripts from the Nachlass of deceased colleagues such as Golius (1596-1667) in Leiden, from whom he secured 31 manuscripts, or received them through contacts he had in the East. After Reland's death, however, the university did not buy a single one of the over 2,500 books in his collection and only purchased a modest batch of his 200 or so manuscripts (for which see Appendix 2), auctioned off in 1761. Most manuscripts sold at that auction were bought by individual scholars and collectors, while the only institution that bought manuscripts in significant numbers was the Vatican - which is not without irony, since the Vatican had been quick to put Reland's De religione Mohammedica on its index of forbidden books. They became the foundation of the collection now known as Vaticani Indiani.

Today most of Reland's manuscripts and books are to be found in Leiden University Library, having arrived there through sundry channels. In his second contribution to this volume, Arnoud Vrolijk investigates the role of Reland as a manuscript collector and its traces in the holdings of the Leiden University Library. In 1710, for instance, the French antiquary, numismatist and translator of the 1001 Nights Antoine Galland (1646-1715) sent two Persian manuscript copies with a Latin translation in his own hand to Reland, hoping that he would find the time to edit them. In the extant Leiden manuscript catalogues the Galland provenance is duly noted, but the Reland connection is ignored. Vrolijk tackles the question of whether other Reland manuscripts can be identified with the help of the 1761 auction catalogue, adding reflections on how to read the information buried in the laconic and often misleading descriptions provided by the auctioneer. Leiden bought nothing at the auction, but in spite of this a total of 39 items with a Reland provenance can be identified with varying degrees of certainty. Ironically, this makes Leiden the largest single Reland collection in the world. Building on the legacy of Erpenius (1584-1624) and Golius, Leiden blossomed into the centre of Dutch Oriental studies, including the study of Arabic and Islam. Were it not for his premature death, Reland's great renown as a scholar would likely have firmly established Oriental studies at Utrecht University and helped it to flourish for many decades after his death. 
While the previous section has explained the subtitle of the present volume, our use of the term 'Orient' in the main title requires us to reflect, albeit briefly, on the question of Orientalism, a concept whose continued importance in the humanities today is widely acknowledged.${ }^{13}$ Orientalism, according to Edward Said, is a discourse of political domination that hinges on a sharp division between 'the West' and 'the East'; a 'style of thought based upon an ontological and epistemological distinction made between "the Orient" and (most of the time) "the Occident". ${ }^{14}$ Orientalists position themselves as being 'exterior' to the Orient, 'both as an existential and as a moral fact', which buttresses their claim to authority and the aura of truth in which they clothe their discourse.

In this regard it is instructive to examine, as Christian Lange does in his chapter, how Reland thought and wrote about the prophet of Islam. As Lange's study of De religione Mohammedica and Reland's hitherto unexamined treatise on the Islamic law of war shows, in comparison with the likes of Grotius (1583-1645), Humphrey Prideaux (1648-1724), Henri de Boulainvilliers (16581722), and Voltaire (1694-1778), but also the learned Barthélemy d'Herbelot (1625-1695), Reland offered a new perspective in several ways. First, he hardly ever talked about Muhammad in the derogatory terms that were customary at the time, simply referring to him as 'the prophet'. Secondly, Reland insisted on the exclusive use of authoritative Muslim sources to offer a balanced account of Islam. Reland, thirdly, wanted to listen to Muhammad and his followers as they expressed themselves through texts, judging them to be 'free to follow their own light'.

It is important to remember that in the seventeenth century the concept of the Orient was suddenly extended from the Levant to the Far East and East Indies. Orientalists no longer talked about the entire Orient in the same terms. As Ellen R. Welch notes, '[i]nfluenced by a long tradition of contact and representation, travellers to the Levant portrayed a threatening land ruled by tyrants and mined with seductive, sequestered women'. By contrast, ' $[t]$ he Indes orientales [...] appeared as a fertile paradise of natural riches peopled by indolent or violent barbarians. This depiction of the Indies as a land of unexploited precious resources both reflected and encouraged European economic intervention'. ${ }^{15}$ What, then, was Reland's position in this shifting landscape?

\footnotetext{
13 Ahmed, What is Islam?, p. $5^{26}$ n. 23o. See also Varisco, Reading Orientalism.

14 Said, Orientalism, p. 2. Nuanced and critical rejoinders to Said's seminal work include Hourani, 'The Road to Morocco'; Clifford, 'On Orientalism'.

15 Welch, 'Review of Veiled Encounters', pp. 459-46o.
} 
Did he simply have a 'lust of knowing', the genuine academic curiosity of Orientalist scholars, as stressed by Robert Irwin? ${ }^{16}$ Or was he, at bottom, an ideological advocate of the colonisation of the East by Western states, such as the Dutch Republic? We know, for example, that Reland was in contact with travellers, missionaries and ministers working overseas and in the Dutch colonies, including the minister and naturalist François Valentijn (1666-1727). The church council of Batavia, moreover, wrote a letter on 14 November 1701 to the church council of Amsterdam in which they applauded the appointment of Reland in Utrecht. The council members expressed their hope that the theologians under Reland's care would be trained in the Oriental languages to the extent that they would be able to master the Indian languages. ${ }^{17}$ No doubt knowledge of Eastern cultures, including their languages, was part of the repertoire of 'cultural technologies of [colonial] rule.' ${ }^{18}$

The reasons for Reland's linguistic curiosity are explored in Toon van Hal's chapter in this volume. Reland's interest in foreign languages, which stretched well beyond the classical and Semitic languages he originally studied, was driven by the search for the linguistic kinships that would ultimately help to reveal the original language, and thereby the prehistory of mankind. Reland's linguistic achievements should thus be assessed against the backdrop of debates current at the time-debates which he was not always able to transcend. Notably, Reland was unable to go beyond the Biblical framework positing Hebrew as the world's original language, even when the specimens he collected suggested otherwise.

Elaborating on the topic of Reland's methodology and the issue of Orientalist 'exteriority' in particular, Tobias Winnerling, in his contribution to this volume, takes a closer look at Reland's cartographic work, focussing on two maps by Reland: the somewhat neglected map of Persia from 1705, and a more wellknown map of Japan from 1715. The central question is whether Reland's wellrecognised approach of combining maps with further research on the topic, relying on contemporary indigenous sources, can also be discerned in his single maps. Analysing Reland's methodology and comparing it with that of his contemporaries, Winnerling finds evident parallels between the two maps, especially in the use of source material from the regions concerned. The two maps share a common methodological framework, thus connecting more closely to Reland's overarching research patterns than has been previously recognised.

\footnotetext{
16 Irwin, For Lust of Knowing.

17 Van Boetzelaer, De Protestantsche kerk in Nederlandsch-Indië, p. 252.

18 See e.g. Cohn, Colonialism and its Form of Knowledge, pp. 3-5; Dirks, Colonialism and Culture, p. 3.
} 
Several chapters in this volume show that Reland was constantly engaged in correcting the 'invented traditions' regarding the Orient. Nowhere is this more aptly demonstrated than on the title-page of the first edition of De religione Mohammedica (1705), which promises that the book will 'examine some of what is falsely attributed to the Mohammedans' ('examinat nonnulla, quae falso Mohammedanis tribuuntur'). Reland advocated independent research, the rejection of traditional authority — a key theme of his disputation De libertate philosophandi of 1694 - and promoted the correction of false representations, even if they concerned 'competing' religions. Moreover, he urged everyone to master documents and manuscripts in the original languages.

In his contribution Richard van Leeuwen explores 'to what extent Dutch Oriental studies at the time [of Reland] were placed at the interface between economic and political interests and religious debates'. Reland's Protestantism, in fact, further complicates debates about his alleged Western or Orientalist bias. Thanks to the increasing contact between Europe and the Muslim world, the Islamic pilgrimage, or Hajj, became a focus of interest for both scholars and for transregional actors such as travellers and merchants. The Hajj was seen as a ritual that was gradually being purged of its medieval mystifications. As such, it could contribute to a better comprehension of certain controversies between Catholics and Protestants. 'The Hajj not only symbolised the differences between Islam and Christianity, but also the differences between the northern European Protestants and the Roman Church'. In this respect, Van Leeuwen concludes, the Hajj 'is illustrative of the change in the judgement and appreciation of Islam: in Protestant Oriental studies as practiced by Reland, Islam is not so much a reprehensible Christian sect, but an autonomous religion deserving a thorough and unbiased examination'.

\section{Reland in the Republic of Letters — and Beyond}

As we saw, Reland spent his whole life in Utrecht, far away from the Orient. However, thanks to his talents and his personality, his relatively isolated hometown became a hub for the exchange of information about the Orient between the Dutch Republic, the rest of Europe, and the colonies in the East. Besides the scholars who inhabited the European Republic of Letters, Reland communicated with Dutch East India Company officials, as well as travellers and missionaries. He was in close contact with two magistrates, scholars and collectors of artefacts from the Orient, Gisbert Cuper (1644-1716), mayor of Deventer, and Nicolaes Witsen (1641-1717), mayor of Amsterdam and a one-time bevindhebber ('supervisor') of the Dutch East India Company. At Reland's request Witsen 
intervened to assist him in collecting manuscripts from ministers and travellers in the colonies, including the minister Petrus van der Vorm (1664-1731) and the artist and traveller Cornelis de Bruyn (1652-1726/7) ${ }^{19}$ In her contribution to this volume, Anna Pytlowany reconstructs Reland's wide-ranging social and business network based on what is left of Reland's less formal legacy: his personal and business letters; the books and manuscripts offered to him; and the items mentioned in his auction catalogue, such as coins and scientific instruments. In his funeral oration for Reland, Joseph Serrurier (d. 1742) says that Reland corresponded with scholars and collectors from across the whole of Europe: France, Germany, Switzerland, Denmark, Italy, England, and the Netherlands. ${ }^{20}$ In many cases, only some letters have come down to us, and often none at all. Book dedications, celebratory poems, and inscriptions in several alba amicorum offer glimpses of Reland's private life, friendships and business dealings. From these fragments of Reland's life, a multifaceted image emerges: Reland the scholar and networker; Reland the antiquarian and poet; Reland the colleague and friend. They also give us a taste of the cultural and intellectual climate of Utrecht around 1700. When studied together with the other materials examined in this volume- his scholarly writings, poems, maps, books and manuscripts - they conjure up the image of a man of many talents, a scholar subject to a curious mixture of influences, a critical intellectual endowed with a strong will and a great independence of mind. Reland, as the chapters in this volume demonstrate, developed a new and modern vision of the study of human culture, its artefacts, languages and religions. His vision resonated throughout Europe and continues to inspire to this day.

\section{Bibliography}

\section{Sources}

Burmannus, C., Trajectum eruditum, virorum doctrina inlustrium, qui in urbe Trajecto, et regione Trajectensi nati sunt, sive ibi habitarunt, vitas, fata, et scripta exhibens, Utrecht, Herman and Johan Besseling, 175 .

Reland, A., Disputatio philosophica inauguralis, De libertate philosophandi..., Utrecht, François Halma, 1694.

Reland, A., Oratio De incremento, quod Philosophia cepit hoc seculo..., Amsterdam, Thomas Myls, 1700 .

19 Peters, De wijze koopman, p. 488 n. 3 o.

20 Serrurier, Oratio funebris, pp. 39-40. 
Reland, A., Oratio Pro lingua Persica et cognatis litteris Orientalibus..., Utrecht, Willem vande Water, 1701.

Reland, A., De religione Mohammedica libri duo. Quorum prior exhibit compendium theologiae Mohammedicae..., Utrecht, Willem Broedelet, 1705.

Reland, A., De religione Mohammedica libri duo. Editio altera auctior, Utrecht, Willem Broedelet, 1717 .

Serrurier, J., Oratio funebris in obitum viri celeberrimi Hadriani Relandi, antiquitatum sacrarum et linguarum orientalium professoris ordinarii, recitata ipsis nonis Martiis MDCCXVIII, Utrecht, Willem vande Water, 1718.

\section{Studies}

Aa, A.J. van der, 'Reeland (Adrianus of Handrianus)', Biografisch woordenboek der Nederlanden, vol. 16, Haarlem, J.J. van Brederode, 1874, pp. 145-151.

Ahmed, Sh., What is Islam? The Importance of Being Islamic, Princeton, NJ, Princeton University Press, 2016.

Album studiosorum Academiae Rheno-Traiectinae MDCXXXVI-MDCCCLXXXVI: accedunt nomina curatorum et professorum per eadem secula, Utrecht, J.L. Beijers and J. van Boekhoven, 1886.

Amersfoort, J.van, 'Adrianus Reland als filoloog en godsdiensthistoricus', in A. de Groot and O.J. de Jong (eds), Vier eeuwen theologie in Utrecht: Bijdragen tot de geschiedenis van de Theologische Faculteit aan de Universiteit Utrecht, Zoetermeer, Meinema, 2001, pp. 131-140.

Bevilacqua, A., The Republic of Arabic Letters: Islam and the European Enlightenment, Cambridge, MA, The Belknap Press of Harvard University Press, 2018.

Boetzelaer van Asperen en Dubbeldam, C.W.Th. van, De Protestantsche Kerk in Nederlandsch-Indië: Haar ontwikkeling van 1620-1939, The Hague, Nijhoff, 1947.

Clifford, J., 'On Orientalism', in idem, The Predicament of Culture: Twentieth-Century Ethnography, Literature, and Art, Cambridge, MA, Harvard University Press, 1988, pp. $255^{-276 .}$

Cohn, B.S., Colonialism and Its Forms of Knowledge: The British in India, Princeton, NJ, Princeton University Press, 1996.

Dirks, N.B., 'Introduction', in N.B. Dirks (ed.), Colonialism and Culture. Ann Arbor, The University of Michigan Press, 1992, pp. 1-25.

Dirks, N.B., 'Foreword', in B.S. Cohn, Colonialism and Its Forms of Knowledge: The British in India, Princeton, NJ, Princeton University Press, 1996, pp. ix-xvii.

Gibbon, E., The History of the Decline and Fall of the Roman Empire, first published 1776-1789, 6 vols., New York, Harper \& Brothers, 1862.

Hamilton, A., 'Adriaan Reland: Outstanding Orientalist', in Commissie Geschiedschrijving van de Universiteit Utrecht (eds), Zes keer zestig: 360 jaar universitaire geschiedenis in zes biografieën, Utrecht, Afdeling Grafische Zaken, 1996, pp. 23-31. 
Hamilton, A., 'From a "Closet at Utrecht": Adriaan Reland and Islam', Nederlands archief voor kerkgeschiedenis / Dutch Review of Church History, vol. 78, no. 2, 1998, pp. $243-5$ o.

Hamilton, A., 'The Study of Islam in Early Modern Europe', Archiv fürReligionsgeschichte, vol. 3, 2001, pp. 169-82.

Hamilton, A., 'Arabists and Cartesians at Utrecht', in P. Hoftijzer and T. Verbeek (eds), Leven na Descartes: Zeven opstellen over ideeëngeschiedenis in Nederland in de tweede helft van de zeventiende eeuw, Hilversum, Uitgeverij Verloren, 2005, pp. 97-105.

Hazard, P., The Crisis of the European Mind, 1680-1715, first published 1935, Hammondsworth, Penguin Books, 1964.

Hoek, F., '3oo jaar Adriaan Reland: Hoogleraar Oosterse talen, orientalist, theoloog, Neolatijns dichter en caertograaf', De kroniek: Historisch tijdschrift van Gradt-De Rijp en Schermer, vol. 34, no. 4, 2017, pp. 4-13.

Hourani, A., 'The Road to Morocco: Review of Edward Said's Orientalism', New York Review of Books, March 8, 1979.

Irwin, R., For Lust of Knowing: The Orientalists and Their Enemies, London, Penguin Press, 2006.

Nat,J., De studie van de Oostersche talen in Nederland in de 18e en de 19e eeuw, Purmerend, J. Muusses, 1929.

Peters, M., De wijze koopman: Het wereldwijde onderzoek van Nicolaes Witsen (1641-1717), burgemeester en VOC-bewindhebbervan Amsterdam, Amsterdam, Bakker, 2010.

Rinsum, H.J. van, '1705 Een nieuwe visie op de islam', in L.H. van Voss et al. (eds), Wereldgeschiedenis van Nederland, Amsterdam, Ambo, 2018, pp. 299-304.

Said, E., Orientalism, New York, Vintage Book, 1978.

Shalev, Z., 'Hadriani Relandi Palaestina ex monumentis veteribus illustrata: An Introduction', 2007, https://haifa.userservices.exlibrisgroup.com/view/delivery/972 HAI_MAIN/12177231810002791 (accessed 24 January 2O20).

Varisco, D.M., Reading Orientalism: Said and the Unsaid, Seattle-London, University of Washington Press, 2007, 2nd edn. 2017.

Vrolijk, A. and R. van Leeuwen, Arabic Studies in the Netherlands: A Short History in Portraits, 1580-1950, translated by A. Hamilton, Leiden and Boston, Brill, 2014.

Welch, E.R., 'Review of Veiled Encounters: Representing the Orient in 17th-Century French Travel Literature', French Studies: A Quarterly Review, vol. 63, no. 4, 2009, pp. 459-46o. 